\title{
Kadar Air Kapasitas Lapang dan Bobot Jenis Tanah yang Optimal untuk Pertumbuhan dan Produksi Umbi Uwi (Dioscorea alataL)
}

\section{Water Field Capacity and Optimal Type Weight of Soil for Growth and Production of Bulbs 'Ubi' (Dioscorea alata L)}

\author{
Eko Sulistyono $^{1 *}$ dan Romadhona Abdillah ${ }^{1}$ \\ ${ }^{1 *}$ Departemen Agronomi dan Hortikultura, Fakultas Pertanian, Institut Pertanian Bogor \\ Jl. Meranti, Kampus IPB Darmaga, Bogor 16680, Indonesia \\ e-mail: pengelolaanair@yahoo.com
}

Diterima 7 Januari 2017/Disetujui 20 Maret 2017

\begin{abstract}
Food diversification is one of the ways in order to achieve national food security. One of the alternative food that has the potential to be developed is tuber of Dioscorea alata (uwi, ubi kelapa, keribang, water yam). The aim of this experiment was to determine optimum water content of field capacity and spesific weight of the tuber growing space of Dioscorea alata to produce maximum growth and tuber productivity. The experiment was arranged in Randomized Complete Block Design with five replications. The treatment of this research included without planting hole, with planting hole, husk addition as much as $50 \%$ of planting hole volume, husk and manure addition as much as $50 \%$ and $25 \%$ of panting hole volume, manure addition as much as $25 \%$ of planting hole volume. The result of this experiment shows that the treatment give significant effect on the physical characteristics of the soil and vegetative growth of plants (except plant height variable), but no significant effect in increasing the productivity of tubers. For the physical characteristics of the soil, the addition of planting hole, husks and manure has the lowest value of soil density and the highest value of soil field capacity. For the vegetative growth phase, planting in planting hole and addition of husks and manure has the highest number of leaves and the number of branches. The optimum water content of field capacity and spesific weight of the tuber growing space was $39.68 \%$ dry weight based and 0,69 g. $\mathrm{cm}^{-3}$ respectively.
\end{abstract}

Keywords: tuber growth space, tuber productivity, vegetative growth, yam tuber

\begin{abstract}
ABSTRAK
Diversifikasi pangan merupakan salah satu jalan untuk mencapai ketahanan pangan nasional. Salah satu alternatif bahan pangan yang potensial untuk dikembangkan adalah uwi (Dioscorea alata). Tujuan penelitian ini adalah untuk mendapatkan nilai kadar air kapasitas lapang dan bobot jenis optimumdari ruang tumbuh ubi Dioscorea alata. Penelitian disusun dalam Rancangan Kelompok Lengkap Teracak dengan lima ulangan. Perlakuan daripenelitian ini adalah tanpa lubang tanam, dengan lubang tanam, penambahan sekam sebanyak 50\% volume lubang tanam, penambahan sekam dan pupuk kandang sebanyak masing-masing $50 \%$ dan $25 \%$ lubang tanam, penambahan pupuk kandang sebanyak $25 \%$ lubang tanam. Hasil penelitian ini menunjukan bahwa perlakuan memberikan pengaruh nyata terhadap sifat fisik tanah dan pertumbuhan vegetatif tanaman kecuali tinggi tanaman, tetapi tidak berpengaruh nyata terhadap produksi umbi. Untuk sifat fisik tanah, penambahan lubang tanam, sekam dan pupuk kandang menghasilkan kadar air kapasitas lapang tertinggi dan bobot jenis tanah terendah. Untuk fase pertumbuhan vegetatif, penanaman dalam lubang tanam dan penambahan sekam dan pupuk kandang memberikan jumlah daun dan jumlah cabang terbanyak. Kadar air kapasitas lapang dan bobot jenis yang optimum dari ruang tumbuh umbi masing-masing adalah $39.68 \%$ berat kering dan 0,69 g. $\mathrm{cm}^{-3}$.
\end{abstract}

Kata kunci: pertumbuhan vegetatif, produktivitas umbi, ruang tumbuh umbi, umbi uwi

\section{PENDAHULUAN}

Dioscorea spp banyak ditanam didaerah tropis. Tiga spesies dioscorea menjadi makanan pokok untuk lebih dari 60 juta penduduk di lima negara Afrika Barat, dimana lebih dari $90 \%$ produksi dioscorea dunia dihasilkan ( Andres et al., 2016). Umbi dioscorea mengandung senyawa yang banyak bermanfaat. Dioscorea alata mengandung silver nanopartikel yang berfungsi sebagai antimikrobial (Pugazhendhi et al., 2016). Ubi udara (katak) dari Dioscorea alata baik untuk dikonsumsi karena dapat sebagai anti-inflammasi ( Deyet al., 2016). Ubi bawah tanah 
berfungsi sebagai aktifitas mitogenik. Selain itu juga sebagai antioksidan, hepatoprotetik, anti-ulcer dan anti diabetik (Dey et al., 2014). Kandungan nutrisi dalam ubi berubah selama perkembangan ubi. Aktifitas $\alpha$-amylase meningkat selama periode pertumbuhan umbi, kandungan dioscorin juga meningkat selama pertumbuhan umbi (Huang et al., 2007). Umbi dioscorea dapat digunakan sebagai bahan pengganti dalam produksi saus dengan kandungan lemak 22\% lebih rendah (Tan et al., 2007).

Perbaikan sifat fisik ruang tumbuh umbi seperti bobot jenis tanah dan kemampuan menahan air dapat mempengaruhi pertumbuhan umbi. Bobot jenis tanah dapat diperbaiki antara lain dengan penambahan bahan organik atau pupuk kandang dan pengolahan tanah. Pertumbuhan umbi menurun dengan peletakan umbi pada kedalaman tanah yang lebih dalam karena memiliki berat jenis tanah yang lebih besar (Chang et al., 2016). Ketersediaan air pada ruang tumbuh umbi mempengaruhi pertumbuhan dan bobot kering umbi (Puangbut et al., 2015). Pembentukan umbi sangat sensitif terhadap kekurangan air pada ruang tumbuhnya (Daryanto et al., 2017). Pemberian pupuk kandang dapat memperbaiki sifat fisik ruang tumbuh sehingga meningkatkan produksi umbi (Paul et al., 2016). Kegemburan tanah yang ditunjukan oleh bobot jenis tanah mempengaruhi aerasi tanah sehingga dapat memperbaiki pertumbuhan umbi (Marjanović et al., 2015)

Penanaman dioscorea jarang menggunakan pupuk kimia/anorganik, karena selain penggunaan pupuk kimia lebih diprioritaskan ke komoditas pokok nasional (misal: padi dan jagung) tanaman dioscorea cenderung lebih kuat dan tahan meskipun hanya menggunakan teknik penanaman secara organik. Walaupun begitu, produktivitas tanaman dioscorea di Indonesia masih belum optimal. Peningkatan produktivitas Dioscorea alata secara organik bisa dilakukan dengan berbagai cara, salah satunya dengan menggunakan pupuk kandang, penambahan sekam, maupun dengan cara tanam yang tepat.

Perbaikan ruang tumbuh dalam konteks cara tanam yang tepat sangat berpengaruh pada pertumbuhan dan perkembangan umbi. Hal ini dikarenakan dengan ruang tumbuh yang baik pembentukan umbi di dalam tanah tidak akan terhambat, serta sirkulasi udara dan air yang baik akan membuat pertumbuhan umbi optimal.Penelitian ini bertujuan untuk mendapatkan nilai kadar air kapasitas lapang dan berat jenis tanah yang sesuai untuk ruang tumbuh umbi Dioscorea alata dan mempelajari pengaruhnya terhadap pertumbuhan dan produksi Dioscorea alata.

\section{BAHAN DAN METODE}

Penelitian dilaksanakan mulai bulan Maret 2014 sampai Desember 2014 di lahan penelitian Kebun Percobaan Sawah Baru, Institut Pertanian Bogor, Jawa Barat dengan ketinggian $250 \mathrm{~m}$ diatas permukaan laut.Penelitian dilakukan dengan menggunakan Rancangan Acak Kelompok denganlima ulangan. Perlakuan dari penelitian ini yaitu (M0) tanpa lubang tanam, (M1) dengan lubang tanam, (M2) dengan lubang tanam, ditambah sekam $(50 \%$ volume lubang), (M3) dengan lubang tanam, ditambah sekam (50\% volume lubang) danpupuk kandang (25\% volume lubang), (M4) dengan lubang tanam, ditambah pupuk kandang (25\% volume lubang). Tiap perlakuan diulang lima kali sehingga terdapat 25 satuan percobaan. Data diolah dengan uji F, apabila nyata pada taraf $5 \%$ maka diuji lanjut dengan DMRT (Duncan Multiple Range Test).

Penelitian diawali dengan menyiapkan tempat pembibitan. Lahan untuk pembibitan berukuran $2 \times 1 \mathrm{~m}$ dibersihkan dan diolah, ditambahkan sekam dan pupuk kandang. Bambu berukuran $65 \mathrm{~cm}$ ditancapkan di tiap ujung, kemudian paranet dipasang di atas bambu sebagai penaung. Bibit berupa potongan umbi sepanjang $5 \mathrm{~cm}$ ditanam di tempat pembibitan dengan jarak tanam $20 \times 20 \mathrm{~cm}$, dan ditambahkan furadan, bibit ditutup tanah penuh.Lahan penanaman yang akan digunakan dibersihkan dari sampah, baik organik maupun nonorganik, serta dibersihkan dari semua jenis tanaman. Lubang tanam berukuran $40 \times 40 \times 30 \mathrm{~cm}$ dibuat dengan jarak tanam 1x1m.Persiapan dan pengolahan tanah ini dilakukan seminggu sampai dua hari sebelum pindah tanam.Bibit yang sudah bertunas umur 6 minggu dipindahkan daritempat pembibitan ke lubang tanam yang telah dibuat. Kemudian ditambahkan sekam dan pupuk kandang sesuai dengan perlakuan dan ulangan. Setelah pindah tanam selesai bambu sepanjang $2 \mathrm{~m}$ ditancapkan di sebelah lubang tanam untuk tempat merambat tanaman. Penyulaman dilakukan pada tanaman yang mati setelah pindah tanam. Pemupukan dilakukan dua kali. Pemupukan pertama dilakukan pada $1 \mathrm{MST}$ dengan dosis $10 \mathrm{gr}$ Urea, $10 \mathrm{gr}$ $\mathrm{KCl}$, dan 15gr SP-36 setiap tanaman. Pemupukan kedua dilakukan pada 4MST dengan dosis yang sama. Pemberian pupuk dilakukan dengan cara disebar merata di sekitar tanaman.Pemeliharaan berupa pengendalian gulma dilakukan secara manual, dan waktu pengendalian disesuaikan dengan keadaan lahan.

Pengamatan pertumbuhan dilakukan tiap 2 minggu sejak pindah tanam. Pengamatan terhadap tanah meliputi penghitungan kapasitas lapang tanah dan penghitungan berat jenis tanah.Pengamatan yang dilakukan terhadap tanaman meliputi tinggi tanaman, jumlah daun, dan jumlah cabang. Batang utama diukur dari permukaan tanah sampai ujungtangkai daun teratas. Daun dihitung pada batang utama dan cabang, dihitung yang telah membuka sempurna. Panen dilakukan pada umur 9 bulan. Pengamatan yang dilakukan pada umbi setelah panen meliputi bobot basah umbi panen, kadar air umbi, bobot kering umbi panen, panjang umbi, lebar umbi, dan jumlah jari umbi.

\section{HASIL DAN PEMBAHASAN}

Kadar air pada kapasitas lapang dan bobot jenis tanah dengan nilai yang berbeda-beda diperoleh pada perlakuan dengan cara perlakuan (M0) tanpa lubang tanam (M0), dengan lubang tanam (M1), dengan lubang tanam ditambah sekam 50\% volume lubang (M2), (M3) dengan lubang tanam ditambah sekam 50\% volume lubang dan pupuk kandang 25\% volume lubang (M3), dengan lubang tanam ditambah pupuk kandang 25\% volume lubang (M4). Bobot jenis tanah pada perlakuan tanpa lubang tanam mempunyai nilai lebih besar dibanding perlakuan lainnya. Penambahan 
sekam kedalam lubang tanam menurunkan bobot jenis tanah. Penambahan sekam menurunkan bobot jenis dengan penurunan yang lebih besar jika dibandingkan dengan pembuatan lubang tanam saja (Tabel 1).Nilai bobot jenis tanah yang lebih rendah berarti tanah tersebut memiliki ruang pori total yang lebih banyak dan tanah lebih gembur.

Tabel 1 Kadar air kapasitas lapang dan bobot jebis tanah pada berbagai perlakuan

\begin{tabular}{lcc}
\hline \multicolumn{1}{c}{ Perlakuan } & Bobot Jenis tanah $\left(\mathrm{g} / \mathrm{cm}^{3}\right)$ & Kadar air Kapasitas lapang (\%) \\
\hline (M0) tanpa lubang tanam & $0.883 \mathrm{a}$ & $33.97 \mathrm{~d}$ \\
(M1) dengan lubang tanam & $0.778 \mathrm{~b}$ & $37.27 \mathrm{c}$ \\
(M2) lubang tanam + sekam 50\% volume & $0.654 \mathrm{c}$ & $40.90 \mathrm{ab}$ \\
(M3) lubang tanam + sekam 50\% volume + pupuk & $0.585 \mathrm{c}$ & $42.70 \mathrm{a}$ \\
kandang 25\% volume & $0.750 \mathrm{~b}$ & $38.40 \mathrm{bc}$ \\
\hline M4) lubang tanam + pupuk kandang 25\% v
\end{tabular}

Keterangan : Angka-angka pada baris yang sama yang diikuti oleh huruf yang sama menunjukkan hasil yang tidak berbeda nyata berdasarkan uji DMRT pada taraf 5\%

Tabel 2 Tinggi tanaman pada berbagai aplikasi perbaikan ruang tumbuh umbi

\begin{tabular}{cccccc}
\hline \multirow{2}{*}{ Umur (MST) } & \multicolumn{5}{c}{ Tinggi tanaman (cm) } \\
\cline { 2 - 5 } & M0 (kontrol) & M1 & M2 & M3 & M4 \\
\hline 2 & 21.8 & 91.2 & 78.0 & 77.4 & 12.6 \\
4 & 98.4 & 157.2 & 149.0 & 150.4 & 183.0 \\
6 & 140.2 & 187.6 & 182.6 & 188.0 & 215.8 \\
8 & 181.0 & 213.6 & 215.8 & 222.0 & 243.8 \\
10 & 223.8 & 235.6 & 245.8 & 250.8 & 262.4 \\
12 & 247.8 & 252.4 & 264.0 & 268.8 & 278.2 \\
14 & 264.2 & 265.2 & 280.6 & 284.2 & 287.8 \\
16 & 273.6 & 273.0 & 288.6 & 293.6 & 293.0 \\
20 & 278.8 & 277.6 & 294.4 & 299.0 & 294.2 \\
\hline
\end{tabular}

Keterangan : Angka-angka pada baris yang sama yang diikuti oleh huruf yang sama menunjukkan hasil yang tidak berbeda nyata berdasarkan uji DMRT pada taraf 5\%.

Tabel 3 Jumlah daun Dioscorea alata pada berbagai perlakuan perbaikan ruang tumbuh umbi

\begin{tabular}{crrrrr}
\hline \multirow{2}{*}{ Umur (MST) } & \multicolumn{5}{c}{ Jumlah daun } \\
\cline { 2 - 5 } & M0 (kontrol) & M1 & M2 & M3 & M4 \\
\hline 2 & $7.4 \mathrm{a}$ & $20.6 \mathrm{a}$ & $17.4 \mathrm{a}$ & $13.0 \mathrm{a}$ & $73.4 \mathrm{a}$ \\
4 & $62.4 \mathrm{~b}$ & $71.2 \mathrm{ab}$ & $71.2 \mathrm{ab}$ & $79.2 \mathrm{a}$ & $185.8 \mathrm{ab}$ \\
6 & $174.2 \mathrm{~b}$ & $180.6 \mathrm{ab}$ & $194.8 \mathrm{a}$ & $187.4 \mathrm{ab}$ & $285.6 \mathrm{~b}$ \\
8 & $266.4 \mathrm{c}$ & $267.8 \mathrm{c}$ & $281.8 \mathrm{~b}$ & $304.2 \mathrm{a}$ & $354.2 \mathrm{a}$ \\
10 & $325.2 \mathrm{~b}$ & $332.6 \mathrm{~b}$ & $352.2 \mathrm{a}$ & $361.2 \mathrm{a}$ & $397.4 \mathrm{a}$ \\
12 & $356.8 \mathrm{c}$ & $371 \mathrm{~b}$ & $392.4 \mathrm{a}$ & $405.2 \mathrm{a}$ & $435.4 \mathrm{a}$ \\
14 & $385 \mathrm{c}$ & $402 \mathrm{~b}$ & $424 \mathrm{a}$ & $435.4 \mathrm{a}$ & $441.4 \mathrm{a}$ \\
16 & $392 \mathrm{c}$ & $409.6 \mathrm{~b}$ & $439 \mathrm{a}$ & $450.4 \mathrm{a}$ & $451 \mathrm{~b}$ \\
20 & $399.4 \mathrm{e}$ & $417.2 \mathrm{~d}$ & $442.6 \mathrm{c}$ & $471.2 \mathrm{a}$ & $416.6 \mathrm{a}$ \\
\hline
\end{tabular}

Keterangan : Angka-angka pada baris yang sama yang diikuti oleh huruf yang sama menunjukkan hasil yang tidak berbeda nyata berdasarkan uji DMRT pada taraf $5 \%$.

Kadar air pada kapasitas lapang meningkat dengan pembuatan lubang tanam dan penambahan sekam. Penambahan sekam 50\% volume dan pupuk kandang $25 \%$ volume lubang tanam meningkatkan kadar air kapasitas lapang menjadi $42.7 \%$ dibanding $33.97 \%$ nilai kadar air kapasitas lapang pada perlakuan tanpa lubang tanam (Tabel 1). Peningkatan jumlah ruang pori dapat menyebabkan peningkatan kadar air kapasitas lapang. Peningkatan kadar air kapasitas lapang berarti peningkatan air tersedia bagi tanaman.

Tinggi tanaman tidak dipengaruhi oleh perlakuan dari saat tanam sampai 20 minggu setelah tanam. Kecepatan pertumbuhan tinggi tanaman rata-rata pada umur $4,6,8,10$, $12,14,16,18$ dan 20 minggu masing adalah 5.1, 2.6, 2.4, $2.2,1.4,1.1,0.6,0.4$ dan $0.1 \mathrm{~cm}$ per hari. Ini menunjukan bahwa kecepatan pertumbuhan tinggitanaman menurun setelah berumur 4 minggu setelah tanam. Tinggi tanaman 
pada umur 20 minggu berkisar antara $278.8 \mathrm{~cm}$ dan $301 \mathrm{~cm}$. (Tabel 2)

Penanaman dalam lubang tanam meningkatkan jumlah daun Dioscorea alata dibandingkan penanaman tanpa lubang tanam pada umur 12 sampai 18 minggu setelah tanam. Pemberian sekam dan pupuk kandang pada lubang tanam dapat menambah jumlah daun. Pada umur 20 minggu setelah tanam pemberian sekam dan pupuk kandang dapat meningkatkan jumlah daun sebesar $12 \%$ dibanding dengan

Perlakuan lubang tanam, penambahan sekam dan pupuk kandang dapat memberikan ruang bagi akar untuk tumbuh secara optimal dan penyerapan air dan hara pun menjadi optimal. Penambahan pupuk kandang dan sekam juga turut membantu dalam perbaikan sifat fisik dan biologi tanah. Adanya perbaikan ruang tumbuh dalam tanah tersebut membuat penetrasi akar, drainase, dan aerasi tanah menjadi lebih baik, serta meningkatkan ketersediaan air dan hara dalam tanah. Kondisi tersebut membuat daun-daun dapat tumbuh dan berkembang serta melakukan aktivitas metabolismenya dengan baik. Jumlah daun terus mengalami peningkatan pada umur 2 hingga 14 MST untuk semua taraf perlakuan. Peningkatan jumlah daun mulai turun dan mendekati konstan pada umur 16-18 MST, dan jumlah daun mulai menurun pada $20 \mathrm{MST}$.

Tanaman yang ditanam pada lubang tanam berisi 50 $\%$ sekam dan $25 \%$ pupuk kandang mempunyai jumlah cabang lebih banyak dibandingkan perlakuan lainnya. Secara umum tanaman dengan penambahan lubang tanam, sekam dan pupuk kandang menghasilkan jumlah cabang paling banyak, sedangkan jumlah cabang paling sedikit dihasilkan tanaman kontrol (Tabel 4). Peningkatan jumlah penanaman tanpa lubang tanam yaitu 413.6 dibanding dengan 370 daun (Tabel 3). Peneliti lain melaporkan bahwa pemberian pupuk kandang dapat meningkatkan indeks luas daun dan kecepatan pertumbuhan (Yarami dan Sepaskhah, 2015), meningkatkan tinggi tanaman dan berat kering tanaman (Rehman et al., 2015). Pemberian pupuk kandang dengan cara dicampur kedalam tanah menghasilkan pertumbuhan yang lebih baik dibanding dengan cara disebar kepermukaan tanah (Adekiya dan Agbede, 2016). cabang diduga disebabkan oleh kecepatan fotosintesis yang meningkat akibat perlakuan sekam dan pupuk kandang. Liu et al. (2011) melaporkan bahwa pemakaian pupuk organik meningkatkan aktifitas akar dan mempercepat kecepatan fotosintesis sehingga menghasilkan pertumbuhan yang lebih tinggi.

Perlakuan perbaikan ruang tumbuh umbi berupa pembuatan lubang tanam, pemberian sekam dan pupuk kandang tidak berpengaruh nyata terhadap bobot basah umbi, bobot kering umbi, panjang umbi, dan lebar umbi. Bobot umbi basah per hektar setelah dikonversi dari per tanaman untuk tiap perlakuan adalah 8.28 ton (tanpa perbaikan ruang tumbuh umbi), 13.19 ton (penambahan lubang tanam saja), 13.23 ton (penambahan lubang tanam dan sekam), 9.65 ton (penambahan lubang tanam sekam dan pupuk kandang), dan 11.51 ton (penambahan lubang tanam dan pupuk kandang). Perkasa et al. (2016) melaporkan bahwa pemberian pupuk kandang ayam menghasilkan ukuran kanopi lebi besar dibanding tanpa pupuk kandang, tetapi tidak mempengaruhi berat umbi.

Tabel 4 Jumlah cabang pada berbagai aplikasi perbaikan ruang tumbuh umbi

\begin{tabular}{clllll}
\hline \multirow{2}{*}{ Umur (MST) } & \multicolumn{5}{c}{ Jumlah cabang } \\
\cline { 2 - 6 } & M0 & M1 & M2 & M3 & M4 \\
\hline 2 & $1.2 \mathrm{a}$ & $1 \mathrm{a}$ & $1 \mathrm{a}$ & $1.4 \mathrm{a}$ & $1 \mathrm{a}$ \\
4 & $1.4 \mathrm{~b}$ & $1 \mathrm{~b}$ & $1.4 \mathrm{~b}$ & $2 \mathrm{a}$ & $2 \mathrm{a}$ \\
6 & $1.4 \mathrm{~b}$ & $1 \mathrm{~b}$ & $1.4 \mathrm{~b}$ & $2 \mathrm{a}$ & $2 \mathrm{~b}$ \\
8 & $1.4 \mathrm{c}$ & $1 \mathrm{c}$ & $1.4 \mathrm{c}$ & $2.8 \mathrm{a}$ & $2.8 \mathrm{ab}$ \\
10 & $2 \mathrm{bc}$ & $1.6 \mathrm{c}$ & $2.2 \mathrm{abc}$ & $3 \mathrm{a}$ & $5.4 \mathrm{~b}$ \\
12 & $2.6 \mathrm{~cd}$ & $2.2 \mathrm{~d}$ & $3 \mathrm{bc}$ & $4.6 \mathrm{a}$ & $6.6 \mathrm{a}$ \\
14 & $4 \mathrm{~b}$ & $3.6 \mathrm{~b}$ & $3.8 \mathrm{~b}$ & $6.2 \mathrm{a}$ & $5.6 \mathrm{ab}$ \\
16 & $4 \mathrm{~b}$ & $4 \mathrm{~b}$ & $4 \mathrm{~b}$ & $6.6 \mathrm{a}$ & $6.2 \mathrm{a}$ \\
\hline
\end{tabular}

Keterangan : Angka-angka pada baris yang sama yang diikuti oleh huruf yang sama menunjukkan hasil yang tidak berbeda nyata berdasarkan uji DMRT pada taraf 5\%

Tabel 5 Bobot umbi, ukuran umbi, dan kadar air umbi pada berbagai perlakuan perbaikan ruang tumbuh

\begin{tabular}{|c|c|c|c|c|c|c|}
\hline Perlakuan & BB umbi (g) & BK umbi (g) & KA umbi (\%) & $\begin{array}{l}\text { Panjang umbi } \\
(\mathrm{cm})\end{array}$ & $\begin{array}{l}\text { Lebar umbi } \\
(\mathrm{cm})\end{array}$ & Jumlah jari \\
\hline M0 & 828.60 & 233.24 & $69.95 \mathrm{ab}$ & 25.28 & 14.92 & $3.6 \mathrm{ab}$ \\
\hline M1 & 1319.60 & 334.04 & $74.05 \mathrm{a}$ & 27.76 & 22.86 & $4.6 \mathrm{a}$ \\
\hline M2 & 1323.40 & 393.26 & $68.93 \mathrm{~b}$ & 26.06 & 16.90 & $3.0 \mathrm{ab}$ \\
\hline M3 & 965.60 & 308.75 & $69.73 \mathrm{ab}$ & 28.14 & 19.32 & $3.8 \mathrm{ab}$ \\
\hline M4 & 1151.60 & 337.31 & $70.73 \mathrm{ab}$ & 30.16 & 17.22 & $2.8 \mathrm{~b}$ \\
\hline
\end{tabular}


Keterangan : Angka-angka pada kolom yang sama yang diikuti oleh huruf yang sama menunjukkan hasil yang tidak berbeda nyata berdasarkan uji DMRT pada taraf $5 \%$

Hubungan antara bobot jenis tanah $\left(\mathrm{X}\right.$ g.cm $\left.\mathrm{cm}^{-3}\right)$ dengan bobot kering umbi ( $\mathrm{Y}$ gram per tanaman) adalah $\mathrm{Y}=-3867$ $\mathrm{X}^{2}+5355 \mathrm{X}-1486,\left(\mathrm{R}^{2}=0.884\right)$, sehingga dapat dihitung bobot jenis tanah optimum adalah $0,69 \mathrm{~g} . \mathrm{cm}^{-3}$. Tanah dengan bobot jenis lebih tinggi dari $0,69 \mathrm{~g} . \mathrm{cm}^{-3}$ akan menurun bobot umbi, karena tanah lebih padat sehingga pertumbuhan umbi terhambat. Berat jenis tanah merupakan salah satu sifat fisik tanah yang penting, karena keterkaitannya yang erat dengan kemudahan penetrasi akar ke dalam tanah, drainase, serta aerasi tanah. Hubungan antara kadar air kapasitas lapang (X, \% berat kering) dengan bobot kering umbi ( $\mathrm{Y}$ gram per tanaman) adalah $\mathrm{Y}=-4,120$ $\mathrm{X}^{2}+327,0 \mathrm{X}-6128,\left(\mathrm{R}^{2}=0,851\right)$, sehingga dapat dihitung kadar air kapasitas lapang optimum adalah $39.68 \%$ berat kering. Kadar air kapasitas lapang menunjukan kemampuan maksimal dari tanah untuk menyimpan air. Kadar air kapasitas lapang lebih rendah akan menyebabkan air tersedia lebih rendah sehingga tanaman lebih cepat mengalami kekeringaTabel 1. Pengaruh pemupukan terhadap tinggi tanaman, jumlah daun, panjang akardan jumlah bintil akar dan jumlah bunga pada berbagai perlakuan

\section{KESIMPULAN}

Penanaman dalam lubang tanam yang diberi sekam dan pupuk kandang dapat meningkatkan jumlah daun dan jumlah cabang. Kadar air kapasitas lapang optimum untuk produksi umbi adalah $39.68 \%$ berat kering. Bobot jenis tanah optimum adalah 0,69 g.cm ${ }^{-3}$. Pemakaian berbagai jenis pupuk kandang dan pupuk kompos disarankan untuk digunakan dalam budidaya Dioscorea alata..

\section{DAFTAR PUSTAKA}

Adekiya A.O., T.M. Agbede. 2016. Effect of methods and time of poultry manure application on soil and leaf nutrient concentrations, growth and fruit yield of tomato (Lycopersicon esculentum Mill). Journal of the Saudi Society of Agricultural Sciences, January 2016 In Press.

Andres C., O.O. AdeOluwa, G.S. Bhullar. 2016. Yam (Dioscorea spp.). Encyclopedia of Applied Plant Sciences (Second Edition)., Pages 435-441

Chang D.C., J.H. Cho, Y.I. Jin, J.S. Im, C.G. Cheon, S.J. Kim, H.S. Yu. 2016. Mulch and planting depth influence potato canopy development, underground morphology, and tuber yield. Field Crops Research, October, 2016. 197:117-124

Daryanto S., L. Wang, P.A. Jacinthe. 2017. Global synthesis of drought effects on cereal, legume, tuber and root crops production: A review. Agricultural Water Management, January, 2017. 179:18-33
Dey P., S. Ray, T.K. Chaudhuri. 2016. Immunomodulatory activities and phytochemical characterisation of the methanolic extract of Dioscorea alata aerial tuber. Journal of Functional Foods, May, 2016. 23:315-328

Dey P., and T.K. Chaudhuri. 2014. In vitro modulation of $\mathrm{T}_{\mathrm{H}} 1$ and $\mathrm{T}_{\mathrm{H}} 2$ cytokine expression by edible tuber of Dioscorea alata and study of correlation patterns of the cytokine expression .Food Science and Human Wellness, March, 2014. 3 (1):1-8

Huang C.C., P.Y. Chiang, Y.Y. Chen, C.C.R. Wang. 2007. Chemical compositions and enzyme activity changes occurring in yam (Dioscorea alata L.) tubers during growth. LWT - Food Science and Technology,November, 2007. 40 (9):1498-1506

Liu X., G. Ren,Y. Shi. 2011. The effect of organic manure and chemical fertilizer on growth and development of Stevia rebaudiana Bertoni.Energy Procedia, 2011. 5:1200-1204

Marjanović Z., A. Glišić, D. Mutavdžić, E. Saljnikov, G. Bragato. 2015. Ecosystems supporting Tuber magnatum Pico production in Serbia experience specific soil environment seasonality that may facilitate truffle lifecycle completion. Applied Soil Ecology, November, 2017. 95:179-190

Paul J., A.K. Choudhary,S. Sharma, Savita, M. Bohra, A.K. Dixit, P. Kumar. 2016. Potato production through bio-resources: Long-term effects on tuber productivity, quality, carbon sequestration and soil health in temperate Himalayas. Scientia Horticulturae,December, 2016. 213:152-163

Perkasa A.Y., E. Gunawan, S. A. Dewi, U. Zulfa. 2016. The Testing of Chicken Manure Fertilizer Doses to Plant Physiology Components and Bioactive Compound of Dewa Leaf. Procedia Environmental Sciences, 2016. 33:54-62

Puangbut D., S. Jogloy, N. Vorasoot, A. Patanothai. 2015. Responses of growth, physiological traits and tuber yield in Helianthus tuberosus to seasonal variations under tropical area. Scientia Horticulturae, November, 2015. 195:108-115

Pugazhendhi S., P. Sathya, P.K. Palanisamy, R. Gopalakrishnan. 2016. Synthesis of silver nanoparticles through green approach using Dioscorea alata and their characterization on antibacterial activities and optical limiting behavior. Journal of Photochemistry and Photobiology B: Biology, June, 2016. 159:155-160

Rehman M.Z., M. Rizwan, S. Ali, N. Fatima, B. Yousaf, A. Naeem, M. Sabir, H. R. Ahmad, Y. S. Ok. 2016. Contrasting effects of biochar, compost and farm manure on alleviation of nickel toxicity in maize (Zea mays L.) in relation to plant growth, photosynthesis and metal uptake. Ecotoxicology and Environmental Safety ,November, 2016, 133:218-225 
Tan F.J., F.Y. Liao, Y.J. Jhan, D.C. Liu. 2007. Effect of replacing pork backfat with yams (Dioscorea alata) on quality characteristics of Chinese sausage. Journal of Food Engineering,April, 2007. 79 (3):858-863

Yarami N., A. R. Sepaskhah. 2015. Physiological growth and gas exchange response of saffron (Crocus sativus L.) to irrigation water salinity, manure application and planting method. Agricultural Water Management,May, 2015. 154:43-51 